\title{
A reziliencia vizsgálata pedagógusok körében és a pedagógusképzésben
}

\section{Bordás Andrea}

Partiumi Keresztény Egyetem Gazdaság- és Társadalomtudományi Karának adjunktusa

bordas.andrea@partium.ro

Jelen tanulmány a reziliencia fogalmát és annak oktatási térben való alkalmazását járja körül. A magyar nyelvü neveléstudományi szakirodalomban föként a tanulmányi reziliencia fogalmával és vizsgálatával találkozunk. A tanulmány célja egy olyan holisztikus szemléletú, rendszerelméleti megközelités bemutatása, amely jobban illeszkedik a pedagóguskutatások világához, és a maga komplexitásában képes megragadni a szakmai reziliencia fogalmát. A reziliencia dinamikus interaktív modellje lehetőséget ad mind az intézményi oktatási környezet, mind a reziliencia fejlesztésével foglalkozó képzések, továbbképzések újragondolására.

Kulcsszavak: reziliencia, pedagógusképzés, reziliens pedagógus, pályán maradás, a reziliencia dinamikus interaktív modellje

DOI: 10.37205/TEL-hun.2020.3-4.01

\section{A reziliencia meghatározásai különböző tudományok, megközelítések tükrében}

A reziliencia a humán- és társadalomtudományok közkedvelt fogalmává vált az utóbbi évtizedekben. Annak oka, hogy számos tudományterület megtalálja alkalmazásának lehetőségét Szokolszky és V. Komlósi (2015) szerint rendszerfogalomjellegében rejlik. A kutatók jelentős csoportja definiálja ma már a rezilienciát a rendszerelmélet és az ökológia nézőpontjából, ahol a hangsúly egyrészt a vizsgált szervezet homeosztázisának megteremtésére, visszaállítására esik (Cicchetti \& Lynch, 1993; Szokolszky \& V. Komlósi, 2015; Szokolszky et al., 2015), másrészt pedig a rendszerek közötti folyamatos kölcsönhatásokra (Shafi \& Templeton, 2020). Egy adott szervezet, rendszer, ökoszisztéma funkcionális fennmaradása akkor biztosított, ha súlyos müködési zavar, sokkhatás esetén képes a kibillent egyensúly visszaállítására. Ha sikeres, ebben a visszaállítási folyamatban megmutatkozik és fejlődik is a rendszer rugalmas ellenálló képessége, azaz rezilienciája. Az önfenntartás mellett ez a folyamat tartalmazza az ön-újraszerveződés mozzanatát is, ami 
lehetővé teszi az előző egyensúlyi állapot meghaladását (Szokolszky \& V. Komlósi, 2015). Attól függően, mit tekintünk vizsgálatunk tárgyának: egy személyt, egy közösséget, egy intézményt, egy települést - mivel mind értelmezhetők komplex dinamikus rendszerként - a reziliencia jelenségét nagy valószínűséggel kirívó példaként, váratlan fejlődési útként fedezzük fel vizsgálódás közben.

Az utóbbi fél évszázadban, még ha csak érintőlegesen is, számtalan kutatás látóterébe került be a reziliencia, de központi fogalommá, a tudományos kutatás egyértelmủ tárgyává a 21. században vált. Mivel a pszichológiai irányzatok és más tudományterületek is különböző perspektívából közelítenek a reziliencia konstruktuma felé, ugyanakkor folyamatosan bővül a rezilienciával foglalkozó szakirodalom, mindenki által elfogadott, egyértelmű meghatározás nincs. Ha a fogalommeghatározások közös metszetét keressük, akkor a következő szavakkal fogunk találkozni: veszélyeztető környezet, hátráltató körülmények, zavar; sebezhetőség; rizikófaktorok, protektív faktorok; ellenálló képesség, hatékony, adaptív megküzdés; alkalmazkodás; a nehéz körülmények, traumák ellenére való boldogulás, pozitív fejlődés a megküzdés közben/után (Homoki, 2016, 2020).

Attól függően, hogy mennyire szűken vagy tágan értelmezik a hátráltató körülményeket, és milyen természetűek ezek a normális fejlődést veszélyeztető nehézségek, Masten és munkatársai (1990) három helyzetet írnak le:

1) hosszan tartó nehézségek, veszélyeztető körülmények (szegénység, szülők alacsony iskolázottsága, alacsony szocio-ökonómiai státusz, instabil család, a szülők mentális betegségei);

2) kihívást jelentő körülmények, események (háború, természeti katasztrófa, szerencsétlenség, szülők, hozzátartozók elvesztése, válás);

3) akut traumák (zaklatás, bántalmazás, elhanyagoló nevelés, bűnügyek szemtanúi, elszenvedői).

Habár a leírt helyzetek között van némi átfedés, ezek más-más tudományterületek kutatási fókuszába kerültek. Az elsővel inkább a szociológiai, oktatásszociológiai kutatások, a hátrányos helyzettel foglalkozó kutatók foglalkoznak, és a hátrányos helyzet ellenére jól teljesítő személyeket emelik kutatásuk középpontjába (Ceglédi, 2012; Homoki, 2014; Kovács \& Fekete, 2014; Homoki \& Czinderi, 2015; Máté, 2015; Ceglédi, 2018; Fehérvári et al., 2018; Hüse \& Ceglédi, 2018). A másodikra inkább a stresszkezelés irodalmában találunk példákat, ahol azt vizsgálják, milyen megküzdési mechanizmusokkal rendelkezik, milyen mechanizmusokat sajátított el az egyén belső integritása megóvása érdekében (Masten et al., 1990; F. 
Lassú et al., 2015; Lazsádi, 2015; Crane et al., 2018; Vicente de Vera García, 2020). A harmadik pedig a fejlődéslélektan, pszichiátria, különböző terápiák látóterébe került be, ahol a traumákból való felépülés folyamatára koncentrálnak a kutatók (Sz. Makó \& Kiss, 2015).

A neveléstudományok érdeklődésére mindhárom Masten és munkatársai (1990) által leírt helyzet számot tarthat, mégis leginkább az elsővel találkozunk a pedagógiai szakirodalomban. A magyar nyelvủ szakirodalomban oktatási, tanulmányi vagy akadémiai rezilienciaként hivatkoznak a hátrányos helyzet (legtöbbször alacsony szocioökonómiai státuszú család) ellenére jól teljesítő tanulókra a közoktatás színterén (Tóth et al., 2016; Patakfalvi-Czirják, Papp \& Neumann, 2018) és a felsőoktatásban is (Ceglédi, 2012; Ceglédi, 2018; Hüse \& Ceglédi, 2018). Ezeknek a kutatásoknak egy részében az OECD PISA-mérésekre operacionalizált rezilienciafogalmát ${ }^{1}$ alkalmazzák, vagy létrehoznak egy olyan változót, ${ }^{2}$ ami megfoghatóvá, körülhatárolhatóvá teszi a jelenséget. Ahol pszichológiai szemszögből vizsgálják a tanulmányi rezilienciát, ott a stresszkezelés, a megküzdés kerül előtérbe (Kóródi \& Szabó, 2019), és különböző pszichológiai tesztek, skálák alkalmazása biztosítja a reziliensek azonosítását.

A reziliencia komplex konstruktumát modellek segítségével igyekeztek megérteni az elméletalkotó szakemberek és az empirikus kutatók is. Ezekben a modellekben legtöbbször kiemelt szerepet kapnak a (külső és belső) rizikófaktorok, veszélyforrások és a (külső és belső) protektív vagy kompenzáló faktorok, erőforrások, az egyén és interperszonális kapcsolatai, a környezeti és személyes faktorok közötti folyamatos kölcsönhatások, valamint a személy intraperszonális történései (Homoki, 2020). Anélkül, hogy most részletesen bemutatnánk ezeket a modelleket, elmondhatjuk, hogy általában sem a rizikó, sem a protektív faktorok nem egyedül, hanem csoportosan jelentkeznek, hatásuk pedig nemcsak kumulálódik, de exponenciálisan növekszik is (Luthar \& Cicchetti, 2000; Wald et al., 2006; Ceglédi, 2012; Erdei, 2014-2015). Legtöbb esetben minél több rizikófaktort azonosítunk egy helyzetben, annál valószínűbb, hogy az egyén nem képes hatékonyan megküzdeni, sikeresen adaptálódni a körülményekhez. Ez alól két kivételt tárgyal a szakirodalom: a protektív lánc hatását és az ugródeszka-jelenséget. Ha a védő-

\footnotetext{
${ }^{1}$ A PISA vizsgálatokban reziliensnek tekintik azokat a diákokat, akik eredményeik alapján a felső, de szocioökonómiai státuszuk szerint az alsó harmadba, később negyedbe tartoznak (Ceglédi, 2018; Patakfalvi-Czirják, Papp \& Neumann, 2018).

${ }^{2}$ Ceglédi (2018) például a háttérindexek és az eredményességi indexek klaszteranalízisével jut el a reziliensígéretek csoportjának azonosításához.
} 
faktorok egy megfelelő erősségủ ún. protektív láncot képeznek az egyén köré, az egyén több rizikófaktor ellenére is képes kimagasló eredményeket elérni, megfelelően adaptálódni, boldogulni (Luthar \& Cicchetti, 2000). Ceglédi (2018) azokra az esetekre hívja fel a figyelmet az ún. ugródeszka-jelenség kapcsán, amikor a nagyon rossz körülmények mintegy edzőteremként funkcionálnak, és messze az elvárható szint fölé emelik az egyének teljesítményét. Itt a megküzdés folyamatában és annak eredményeként erősödik a reziliencia.

A kutatók többsége (Masten et al., 1990; Cicchetti \& Lynch, 1993; Wald et al., 2006; Szokolszky \& V. Komlósi, 2015; Mansfield et al. 2016; Beltman, 2021) egyetért abban, hogy a reziliencia helyzet- és kontextusfüggő jelenség: egy személy viselkedhet reziliens módon élete egyik területén, míg a másik területen nem (Sameroff, 2005 idézi Ceglédi, 2012), és ugyanazok a rizikótényezők vagy protektív tényezők sem ugyanúgy hatnak különböző embereknél, különböző élethelyzetekben (Herrman et al., 2011), sőt, ugyanazok az egyéni és környezeti tényezők helyzettől, kontextustól függően lehetnek veszélyeztető és védőfaktorok is (Erdei, 2014-2015; Szokolszky \& V. Komlósi, 2015; Shafi, 2020). A reziliencia tehát relatív, folyamatos változásban van életünk során, dinamikus folyamatokat feltételez (Mansfield et al., 2012, 2016), nem velünk született vagy állandó jellemzőnk, hanem megfelelő körülmények között tanulható, fejleszthető (Homoki, 2014, 2016). Személyes jellemzők, kompetenciák, a megélt életesemények és a társas környezet pozitív hatása egymástól függetlenül és együtt is hozzájárulnak a reziliens viselkedés kialakulásához és fejlődéséhez (Gu \& Day, 2013).

\section{A reziliencia dinamikus interaktív modellje (DIMoR)}

A tanulmány szűkebb témája miatt egyetlen modellt vázolunk fel, amely holisztikus szemléletével és részletgazdagságával tűnik ki a többi közül. Adeela ahmed Shafi, Tristan Middleton, Richard Millican és Sian Templeton könyvükben (Shafi et al., 2020) a reziliencia dinamikus interaktív modelljét (Dynamic Interactive Model of Resilience, DIMoR) és annak alkalmazását mutatják be. Rendszerszemléletű ökológiai modelljük az előző reziliencia értelmezések, modellek legfontosabb elemeire épít, azokat helyezi el egy komplex, számtalan kölcsönhatást mutató rendszerben (Shafi \& Templeton, 2020). Daniels és munkatársai 1999-es modelljéből kiindulva és azt némiképp átalakítva a rezilienciát a sebezhetőségtől a sérthetetlenségig tartó spektrumon értelmezik, és hangsúlyozzák a protektív faktorok és a 
kockázati tényezők interaktív természetét. Értelmezésükben ennek a két dimenziónak a kereszteződésében alakul ki a reziliencia (lásd 1. ábra).

$\mathrm{Az}$ egyént körülvevő kontextus rendszerszerüségét, a rendszerek körkörös, egymásba ágyazódó jellegét és a köztük lévő folyamatos kapcsolatot pókhálóábra szemlélteti a modellben, ami Bronfenbrenner ökológiai fejlódéslélektani magmodelljének az adaptációja (Bronfenbrenner, 1979 idézi Shafi \& Templeton, 2020). A különböző rétegek folyamatosan kölcsönhatásban vannak egymással, és a köztük lévő határok rugalmasak. Ezekben a szűkebb-tágabb kontextusokban élik mindennapjaikat az emberek, és itt jelennek meg a protektív és a rizikófaktorok.

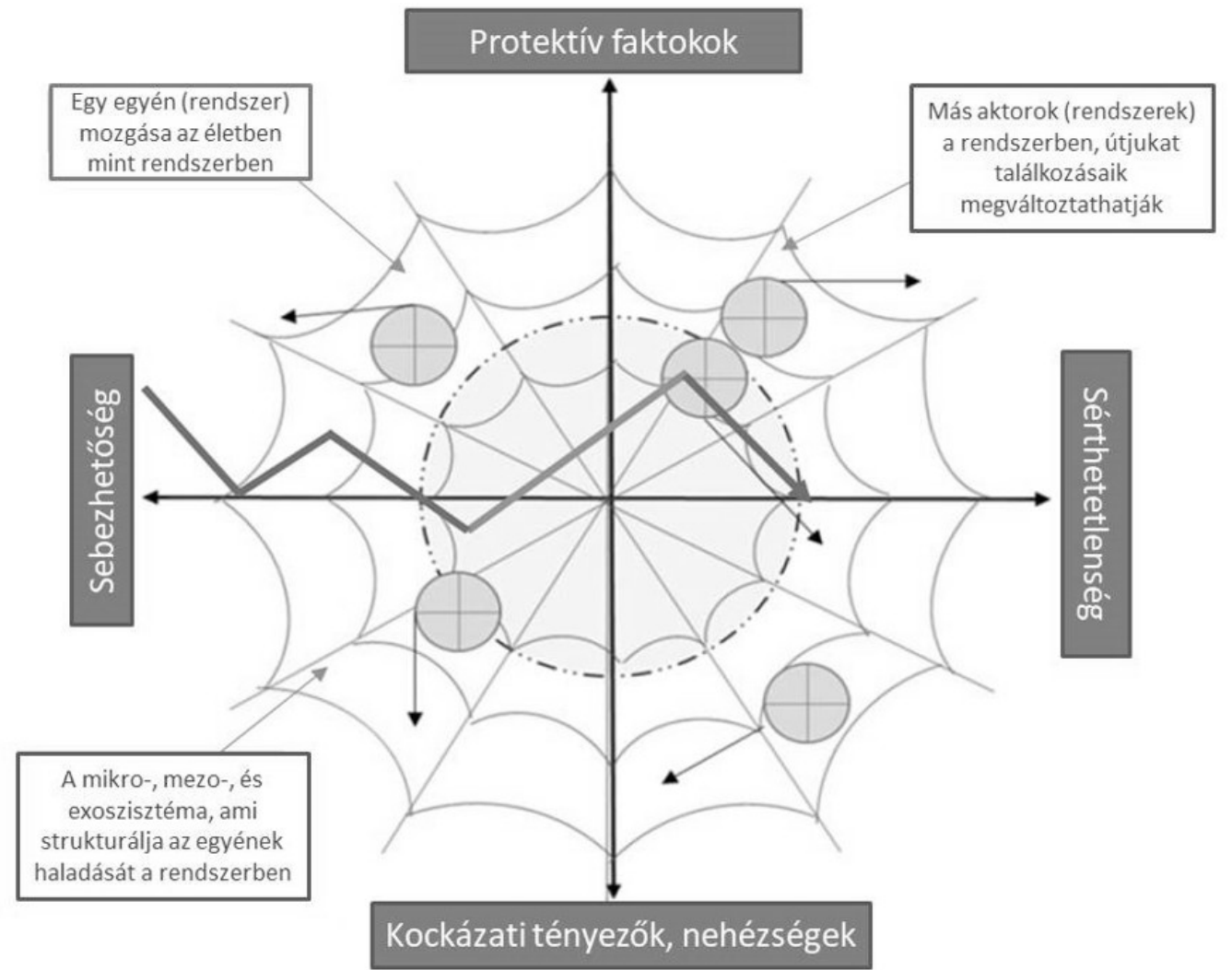

1. ábra: A DIMoR-modell (Forrás: Shafi \& Templeton, 2020)

A pókhálóábrában a rizikófaktorok és a protektív faktorok kumulatív hatása helyett a proxemitás kap kiemelt figyelmet. A szakirodalomban eddig is megkülönböztettek közeli és távoli, protektív, illetve rizikófaktorokat. Erdei (2014-2015) a kockázati tényezőket rendszerezi az egyéni rizikótényezőktől a családi, oktatás- 
sal-neveléssel, kortársakkal kapcsolatos tényezőkön, valamint a tágabb közösség rizikótényezőin keresztül a társadalmi szintű kockázatokig. Elemzésében nagyon jól beazonosíthatóak azok az egyént körülvevő rendszerek, amiket a DIMoRmodell is használ. Ungar és munkatársai viszont (2013 idézi Shafi \& Templeton, 2020) kutatásaik során arra a következtetésre jutottak, hogy minél közelebb vannak a protektív vagy a kockázati tényezők az egyénhez, minél közvetlenebbül kerülnek kapcsolatba vele, annál erősebben hatnak. Ahhoz viszont, hogy a reziliencia kialakulhasson, mindenképp szükség van kockázati tényezőkre, nehézségekre, kihívásokra, ahogy arra már több kutató is rámutatott (Luthar \& Cicchetti, 2000; Tait, 2008; Ceglédi, 2012; Crane et al., 2018).

Mivel a bemutatott egymásba ágyazott körkörös rendszerek kölcsönösen befolyásolják egymást, Shafi és Templeton (2020) ezt a pókhálómodellt elengedhetetlennek tartja a reziliencia vizsgálatában. A szerzők hangsúlyozzák, hogy ebben a szemléletben a reziliencia nem egy rendszeren belül értelmezendő állandó jellemző, hanem rendszeren belüli és különböző rendszerek közötti interakció eredményeként jön létre. A rendszerek önirányító, válaszadó képessége a modell egyik alappillére: hiszen az egyén (mint rendszer) adott körülmények, rizikófaktorok és rendelkezésre álló erőforrások alapján, más rendszerekkel való találkozás során kapcsolatba lép környezetével, reagál a kontextusra. Az, hogy az egyén merre mozdul el a sebezhetőség-sebezhetetlenség, illetve a kockázat-védelem dimenziói által strukturált térben, egyéni hatóerejétől, proaktivitásától is függ. Mozgását pedig meghatározza a kontextus és ezen belül a más rendszerekkel való találkozás is. Az egyéni reziliencia befolyásolja a közösségi rezilienciát, és fordítva: egy reziliens közösségben az egyén is sokkal inkább hozzáfér rezilienciáját előmozdító erőforrásokhoz, viselkedésmintákhoz. Épp ezért a reziliencia nem állandó, hanem az idő és a kontextus függvényében folyamatosan változó jelenség (Shafi \& Templeton, 2020).

\section{A DIMoR alkalmazása az oktatási térben}

Azt, hogy az iskola a gyerekek, fiatalok rezilienciájának fejlesztésében kiemelt szerepet tölt(het) be, több kutató kiemeli (Ceglédi, 2012), ugyanakkor legtöbben azt is belátják, hogy az iskola ugyanúgy lehet rizikófaktor, mint protektív faktor (Homoki, 2014; Erdei, 2014-2015; Shafi, 2020).

A DIMoR különösen jól alkalmazható az intézményes oktatási térben. A helyi társadalomba, kultúrába ágyazott komplex alrendszerként az iskola eleve egy di- 
namikus, interaktív, komplex rendszer, amely folyamatos kölcsönhatásban van más társadalmi alrendszerekkel. Az iskola többrétegü rendszerén belül különböző aktorok találkoznak egymással, és ezek a találkozások befolyásolják az egyének mozgását ebben a térben (Shafi, 2020).

Shafi és munkatársai (2020) arra hívják fel a figyelmet, hogy ha a reziliencia fejlesztését tűzzük ki célul, az a rendszerszintű, kulturális szemlélet, amit a DIMoR-modell nyújt, sokkal hatékonyabb és eredményesebb, mint néhány kontextusból kiemelt kompetencia fejlesztése. A reziliencia fejlesztéséhez természetesen szükség van érzelmi, szociális kompetenciák fejlesztésére, pozitív jellemvonások kialakítására, kognitív készségek fejlesztésére is, hiszen ezek jótékony hatását már több kutatás kimutatta (Vicente de Vera García, 2020; Templeton et al., 2020). A készségek, képességek, explicit tananyag tanítása mellett azonban létezik egy másik út is: kialakítani az egész iskolában a reziliencia kultúráját, vagyis előmozdítani támogató hálózatok létrehozását, fejlesztését, minden szinten motiválni és lehetővé tenni a kollaborációt, kapcsolatokat kiépíteni a szülőkkel, a szélesebb közösség szervezeteivel (Gillham et al., 2013 idézi Shafi, 2020; Erdei, 2014-2015; Middleton \& Millican, 2020). Így nemcsak az egyén, de az iskola rezilienciája is fejleszthető, ami aztán visszahat a rendszerben lévő többi aktorra is.

Middleton és Millican (2020) három különböző perspektívát azonosít a tanulók rezilienciájának fejlesztéséhez hozzájárulni kívánó iskolák számára. Egyrészt az iskola mint rendszer elősegítheti a reziliencia kialakulását, fejlődését, ha a kockázati és a protektív faktorok egyensúlyban vannak az iskolában. Másrészt olyan pedagógiai elképzelések alkalmazásának van jótékony hatása, amelyek fejlesztik a rezilienciát: a konstruktivizmusra alapozó, felfedezéses, tapasztalati tanulást támogató pedagógiai koncepcióknak, az élményalapú, személyközpontú pedagógiáknak, a játék tanulási folyamatban való alkalmazásának. Harmadrészt olyan programokkal fejleszthető a gyerekek rezilienciája, amelyek nemcsak az akadémiai teljesítményekre helyezik a hangsúlyt, hanem a transzverzális kompetenciákra is, és a tanárnak is lehetőséget adnak azoknak az interakcióknak a feltárására, amelyek saját rezilienciáját mozdítják elő, hogy aztán az így szerzett tudását kamatoztathassa a diákok körében. A programalapú fejlesztéseknél viszont nagyon fontos a programok adott kontextusra, oktatási környezetre való adaptálása (Templeton et al., 2020). E nélkül szinte elképzelhetetlen a siker.

A DIMoR-modell iskolai alkalmazását azért is fontos megértenünk, mert bármelyik aktor szemszögéből lépünk is be az iskolarendszerbe, bonyolult kapcsolat- 
hálók, kölcsönös meghatározottságok által tagolt térben fogjuk találni magunkat. Ha a pedagógust helyezzük a DIMoR-modell középpontjába, más hangsúllyal kerülnek be a modellbe különböző aktorok, rendszerek, struktúrák, mást tekinthetünk veszélyeztető és mást védőfaktornak, de az iskola mint munkahely szervezeti felépítésével, légkörével, ethoszával ugyanúgy hat a pedagógusokra is, mint az ott tanuló gyerekekre (Shafi \& Templeton, 2020). A gyermekek rezilienciájának fejlődésére pedig az iskola és a pedagógusok rezilienciája ugyanúgy hatással van (Middleton, 2020; Templeton et al., 2020).

\section{A reziliens pedagógus - a reziliencia vizsgálata pedagógusok körében}

A reziliencia vizsgálata fóként a nyugati oktatási rendszerekben tapasztalható nagyarányú pályaelhagyás miatt került az utóbbi évtizedekben a pedagóguskutatások középpontjába. A gazdasági, társadalmi, technikai változások hatására kiterjesztett pedagógusszerep és az egyre sokrétúbbé váló munka, illetve a pedagógusok társadalmi megbecsültségének jelentős csökkenése olyan aránytalanságot okozott a befektetett munka és a jól megérdemelt jutalmazás között, ami főként a pályakezdőket a pedagógus pálya elhagyására sarkallta. A pedagógiai kutatások eleinte egyfajta deficit-szemlélettel inkább a pályaelhagyás okait vizsgálták, azt, hogy milyen hiányosságokkal, problémákkal küzdenek a pályaelhagyók (például megfelelő kompetenciák hiánya, kiégés, stb.), az utóbbi két évtizedben azonban a pozitív pszichológia hatására itt is fókuszváltás tapasztalható, az erősségalapú megközelítésben a hangsúly a pályán maradásra és a pályán maradást elősegítő tényezőkre helyeződik (Gu \& Day, 2007; Tait, 2008; Johnson et al., 2010; Beltman et al., 2011; Gu \& Day, 2013; Le Cornu, 2013; Mansfield \& Beltman, 2015). A pedagógusok kiégésének vizsgálata mellett egyre több kutatás foglalkozik a pedagógusok rezilienciájával vagy a két jelenség egymáshoz való viszonyával (Tompa, 2013; Donders, 2020; Vicente de Vera García, 2020).

Mivel a pályakezdők között a legmagasabb a pályaelhagyók aránya, a kutatások jelentős része az első évek kihívásait és az azokkal való megküzdést tárgyalja (Tait 2008; Johnson et al., 2010; Le Cornu, 2013). A kutatások másik csoportja a minőségi pályán maradásra koncentrál, nem mellékes ugyanis az, hogy kik, milyen motivációval, elkötelezettséggel, elvekkel és nézetekkel maradnak meg a pedagógushivatás mellett. Gu és Day (2007) egy háromszáz fős longitudinális interjús vizsgálat alapján akkor beszélnek minőségi pályán maradásról, s ennek kap- 
csán rezilienciáról, ha a pedagógusoknak szembenézve munkájuk, életük kihívásaival pedagógusi életpályájuk minden szakaszában sikerül megőrizniük motivációjukat, elkötelezettségüket. A kutatások harmadik csoportja az eddigieknél szűkebben értelmezi a tanári rezilienciát. Pedagógusok életútjának vizsgálata során a tanulmányi reziliencia ${ }^{3}$ fogalmát és a pedagógus egyéni hatóerejét (képes előmozdítani tanítványaiban a reziliencia fejlődését) alkalmazva határozza meg, kik a reziliens pedagógusok (Kozma \& Ceglédi, 2020).

Amikor a pedagógus belép az iskolába, gondolkodását meghatározzák előzetes személyes és szakmai tapasztalatai, élettörténete, különböző rendszerekben elfoglalt helye, és mindezek szűrőként működnek: befolyásolják helyzetfelismerését, reakcióit, interakcióit. A pedagógusok számára a mindennapi iskolai gyakorlat a kiszámíthatatlan helyzetek, folyamatos intellektuális és emocionális kihívások helye (Gu \& Day, 2007; Johnson at al., 2010; Gu \& Day, 2013). Itt az alkalmazkodás nem opció, hanem kényszer, éppen ezért a reziliencia a minőségi pályán maradás záloga. A reziliens pedagógus mindamellett, hogy sikeresen építi fel szakmai identitását (Gu \& Day, 2007; Le Cornu, 2013), ébren tartja lelkesedését, hivatástudatát, odafigyel személyes jóllétére, minden nehézség ellenére a lehető legjobb szakmai teljesítmény érdekében képes a rendelkezésére álló erőforrásokat megkeresni és használni (Hiver, 2018). A tapasztalatokból és az azokra történő reflektálásból való tanulás, a problémahelyzetek, nehézségek kihívásként, tanulási, fejlődési lehetőségként való értelmezése is jellemző a reziliens pedagógusokra (Tait, 2008), s ennek a képességnek a fejlesztése a reziliencia megerősítését eredményezi (Crane et al., 2018).

A pedagógusi pályán a rezilienciát nagymértékben meghatározzák a pedagógus személyes képességei, erőforrásai, értékrendszere, pedagógiai nézetei, de olyan külső tényezők is, mint az intézmény vezetősége részéről érkező támogatás, a kollegiális kapcsolatok minősége, a kollégák elkötelezettsége, a munkahelyi körülmények (Johnson et al., 2010; Gu \& Day, 2013; Le Cornu, 2013; Gibbs \& Miller, 2014; Hiver, 2018). Többszáz féligstrukturált interjú elemzését követően $\mathrm{Gu}$ és Day azt találták, hogy maguk a pedagógusok is egyéni, kapcsolati és szervezeti körülményeikbe mélyen beágyazott faktorok kombinációjaként tekintenek a rezilienciára. A pedagógusi életpálya különböző szakaszaiban megtapasztalt személyes és szakmai identitás, az énhatékonyság érzése és az ezek között kialakuló bo-

${ }^{3}$ A tanulmányi reziliencia a tanulmányi eredményességet helyezi a fogalom középpontjába. Ebben az elképzelésben azt tekintik reziliensnek, aki hátrányai ellenére kiváló tanulmányi teljesítményeket tud felmutatni, sikeres iskolai karriert fut be. 
nyolult meghatározottsági viszonyok járulnak hozzá a reziliencia kialakulásához, ami a pedagógus hatékonyságának alapvető feltétele. Ezekre a kutatási eredményekre alapozva Gu és Day $(2007,2013)$ kiemelik a pedagógusok rezilienciájának szociálisan megkonstruált, folyamatosan fejlődő, dinamikus, kontextusfüggő jellegét.

Mansfield és munkatársai több empirikus munka alapján összegyüjtötték azokat az egyéni jellemzőket és készségeket, képességeket, amelyek a reziliens pedagógusokat jellemzik (Mansfield et al., 2012; Mansfield et al., 2016a). Belső protektív faktorok szerintük az altruizmus, az erős belső motiváció, a morális és szakmai elhivatottság, a kitartás, az optimizmus, a humorérzék, az érzelmi intelligencia, a kockázatvállalási kedv és a rugalmasság. Ezek a tulajdonságok segítenek a pályakezdés első éveinek valóságsokkja ellenére nemcsak túlélni a nehézségeket, de túl is lendülni rajtuk. A pályakezdőknél Mansfield és munkatársai (2012) azt tapasztalták, hogy épp a pedagógus munka komplexitásával, a mindennapok problémás helyzeteivel való szembesülés készteti szakmai, érzelmi, motivációs és szociális dimenzióban is fejlődésre a pedagógust. A reziliens pedagógusok kiemelkedő szociális, emocionális és szakmai készségekkel, képességekkel rendelkeznek. Az előzetes kutatások alapján a megküzdési stratégiák (köztük proaktív problémamegoldó készségek és a segítség megkeresésére irányuló készségek), a kudarctűrés képessége, a stresszkezelés képessége, az érzelmi kompetenciák, valamint olyan különböző interperszonális készségek válnak fontossá a reziliencia szempontjából, amelyek lehetővé teszik a jó társas kapcsolatok és a társas támogató környezet kialakítását (például asszertivitás). A kutatások másik csoportja a reziliens pedagógusok olyan szakmai készségeire, tudására hívja fel a figyelemet, mint a sokszínű módszertani kultúra, a tanulókra való odafigyelés, reagálás a szükségleteikre, a reflektivitás, az elkötelezettség a szakmai fejlődés, tanulás mellett. Mindemellett a reziliens pedagógusok nem kételkednek saját hatékonyságukban és tanítási képességeikben sem (Mansfield et al., 2012, 2016a). Kutatásaik eredményeként a tanári reziliencia négy dimenzióját azonosítják: a szakmai, az érzelmi, a motivációs és a társas dimenziót (Mansfield et al., 2016b), amelyek reziliencia-fejlesztési modelljük alappillérei lesznek (erről lásd később).

Több kutató kiemeli az iskolai klíma és a pedagógusok társas kapcsolatainak, közösségeinek szerepét a kezdő pedagógusok pályán maradása és a reziliencia kialakulása szempontjából (Mansfield et al., 2012; Gibbs \& Miller, 2014; Shafi \& Templeton, 2020). A tanuló szakmai közösségként működő intézmények protektív 
környezeti faktorokat biztosítanak (Johnson et al., 2010; Gu \& Day, 2013; Le Cornu, 2013), ezek az intézmények ugyanis nemcsak a tanulók, hanem a tanárok számára is hatékony tanulási környezetet jelentenek, ahol szakmai fejlődésük megvalósulhat. A pedagógusok bevonása felelősségteljes döntésekbe, olyan szervezeti struktúra kialakítása, ami lehetővé teszi a tudásmegosztást, ahol a kollegiális viszonyok kölcsönös bizalmon, megbecsülésen alapulnak (Stoll at al., 2006, Bordás, 2012a, 2012b, 2017) épp azokat az erőforrásokat biztosítják a pályakezdőknek (de a régebb óta pályán lévőknek is), amelyekre szükségük van ahhoz, hogy sikeresen megbirkózzanak a nehézségekkel, a kihívásokkal, hogy megélhessék szakmai hatékonyságukat és fenntartsák szakmai elkötelezettségüket.

A pedagógusok többsége morális, etikai értékektől vezérelve erős belső motivációval kezd neki a pályának. A mások életének megváltoztatására törekvés és a hit abban, hogy ez sikerülhet, erős szakmai elkötelezettséghez vezet, és egyúttal intellektuális, emocionális és spirituális erőt kölcsönöz. Ha a pedagógus erős pozitív kötődéseket tapasztal meg tanítványaival, azok szüleivel, kollégáival és az intézmény vezetőivel, ha elismerést kap ezektől a fontos partnerektől, ha megéli saját szakmai hatékonyságát, eredményességét, reziliens tud maradni ( $\mathrm{Gu} \&$ Day, 2007, 2013; Johnson et al., 2010). A szakmai elkötelezettség erodálódásának egyik legfontosabb oka a szerepkörből adódó társas kapcsolatok megromlása, nem megfelelő működése. A védőhálóként működő támogató közösség, a kollégákkal közösen megvalósuló szakmai tanulás, a szakmai tapasztalatok folyamatos megosztása, a pozitív visszajelzés, amit egy tanuló szakmai közösség nyújtani tud, épp ezért kulcsfontosságú a pedagógusok szakmai rezilienciája szempontjából (Stoll et al., 2006; Stoll \& Louis, 2007; Bordás, 2017; Waters, 2019). Mansfield és munkatársai (2016a, b) az egyik leghatékonyabb kontextuális erőforrásként tekintenek a munkahelyi és a munkahelyen kívüli kapcsolatokra.

A reziliencia fejlesztése azért nagyon fontos a pedagógusképzésben és a pedagógus pályán, mert csökkenti a stresszt és a kiégés lehetőségét, viszont fejleszti a szakma iránti elkötelezettséget, a motivációt, a munkával való elégedettséget, a jóllétet, a kompetencia, a szakmai autonómia és az énhatékonyság érzését, ezek pedig hosszútávon kihatnak a tanítás minőségére és közvetve a tanulók tanulás iránti elkötelezettségére, motivációira és eredményességére, valamint rezilienciájára is (Tait, 2008; Middleton, 2020; Middleton \& Millican, 2020; Wang, 2021). 


\section{A reziliencia fejlesztése pedagógusok és pedagógus-hallgatók körében}

A pedagógusok rezilienciájával foglalkozó kutatók (Johnson et al., 2010; Mansfield et al., 2016b; Middleton, 2020; Wang, 2021) nagyrészt egyetértenek abban, hogy nemcsak a pályakezdők számára, de már a pedagógusképzésben részt vevők számára is fontos lenne rezilienciafejlesztő tréningeket, programokat biztosítani. Az önismeret, a reflektivitás, a kommunikációs, stresszkezelési, problémamegoldási stb. készségek és képességek fejlesztése ugyanolyan hangsúlyt kell kapjon a pedagógusképzésben, mint a tantárgyi tartalmi és módszertani ismeretek.

Johnson és munkatársai (2010) öt olyan feltételt azonosítottak, amelyek befolyásolják a pályakezdők rezilienciáját: a kapcsolatokat, az iskola kultúráját, a pedagógus identitását, a pedagógus munka komplex természetét és az oktatási rendszer működésmódját, gyakorlatát. Munkájuk nagyban hozzájárult a későbbi rezilienciafejlesztő programok kidolgozásához, s egyúttal felhívja a figyelmet arra is, hogy az egyénre fókuszáló rezilienciafejlesztés a pedagógus szakmában nem elégséges, figyelni kell az iskola kultúrájára és az oktatási rendszer működésmódjában, szervezeti felépítésében meg kell találni és meg kell erősíteni azokat a feltételeket, amelyek támogatják nemcsak a pályakezdők, de a tapasztalt pedagógusok és a pedagógushallgatók rezilienciájának fejlődését is.

Mivel a reziliencia komplex, folyamatos változásban lévő képesség, folyamat és eredmény is egyben (Beltman, 2021), sok különböző képzési, továbbképzési program hatására fejlődhet a pedagógus rezilienciája is, még akkor is, ha az explicit képzési célok között ez nem szerepel. Ilyenek például az érzelmi intelligenciát, a társas kapcsolatokat, a stresszkezelést, különböző megküzdési stratégiákat, reflektivitást, önismeretet fejlesztő tréningek. Sokszor a pedagógusok és/vagy pedagógusjelöltek rezilienciafejlesztésére vállalkozó programok is csak a képességfejlesztésre, vagy a reziliencia egyik dimenziójára fókuszálnak. Leghatékonyabbnak azonban azok a képzések, tréningek bizonyultak, amelyek komplexen értelmezik a rezilienciát, és tudományos kutatási tapasztalataikra építik a fejlesztéseket. Az utóbbi évtizedben több olyan projekt kidolgozására is sor került, amely a reziliencia komplex, dinamikus modellje alapján törekszik a képzések, tréningek megvalósítására. A továbbiakban ezek közül mutatunk be vázlatosan néhányat. 
A BRiTE (Building Resilience in Teacher Education) ${ }^{4}$ egy kétéves projekt eredménye, melyben öt különböző ausztráliai egyetem oktatói vettek részt Caroline Mansfield szakmai vezetésével. A szakirodalom-feldolgozás után az együttműködés eredménye egy öt modulból álló továbbképzés, illetve egy olyan innovatív online tanulási tartalom lett, amely bárki számára szabadon elérhető angol nyelven. A rezilienciát képességként, folyamatként és eredményként értelmezik, építenek a személyes és környezeti erőforrásokra, valamint ezek dinamikus kölcsönhatására is, és mindezt kontextuális keretbe foglalják. A modulok létrehozásával a kutatási eredmények gyakorlatba ültetése és a gyakorlat segitése volt a céljuk. A BRiTE-t 2014-ben egy 181 főből álló kísérleti csoport tesztelte egy nyolc hetes tanulási periódusban (Mansfield et al., 2016a), majd több országban is használták online és hibrid pedagógusképzési, továbbképzési programokba iktatva (Sikma, 2021). Az eredmények azt mutatták, hogy a program alkalmazása jelentősen hozzájárul mind a pedagógusképzésben részt vevők, mind a pályakezdők rezilienciájának fejlesztéséhez (Mansfield et al., 2016a; Sikma, 2021; Weatherby-Fell et al, 2021).

A BRiTE készítőit az a cél vezérelte, hogy a pedagógusképzésben részt vevők, illetve a már pályán lévő pedagógusok számára is lehetőséget biztosítsanak olyan készségek, képességek, tudás és gyakorlatok elsajátítására, amelyek karrierjük során segíthetik őket saját rezilienciájuk fejlesztésében. Maga az online képzési felület azonban fóként a pályakezdőkre fókuszál, nagyobb hangsúlyt kapnak azok a helyzetek, problémák, amelyekkel pályakezdőként találkozhatnak a pedagógusok. A képzési modell középpontjában a reziliencia fejlesztése áll, körülötte pedig négy dimenzióba tömörítve azok a személyes erőforrások, amelyek fejlesztése együttesen járul hozzá a pedagógusok rezilienciájához. A kiindulópontként szolgáló elméleti jellegű tanulási egységgel együtt a dimenziók adják a képzés öt modulját. Ezeket és tartalmukat röviden az 1. táblázat foglalja össze.

$\mathrm{Az}$ ismertetett modulok mellett bónuszként a BRiTE még egy a tudatos jelenlétre fókuszáló (ún. mindfullness) modult is hozzátoldott a képzéshez, amelynek a segítségével mind a négy dimenzióban fejlesztheti magát a képzés résztvevője. A témában való elmélyüléshez a képzés kidolgozói további egyéni és csoportos képzéseket ajánlanak.

\footnotetext{
${ }^{4}$ A www.brite.edu.au - Az oldal önálló tanulásra alkalmas interaktív online felület
} 
Pedagógusképzés • 19(47), 2020/3-4.

\begin{tabular}{|c|c|}
\hline A modul neve & A modul témakörei \\
\hline $\begin{array}{l}\text { Building resilience } \\
\text { (A reziliencia feilesztése) }\end{array}$ & Mi a reziliencia és miért fontos a tanárok számára? \\
\hline Relationships & Szociális dimenzió: \\
\hline (Kapcsolatok) & $\begin{array}{l}\text { - támogató kapcsolatok, hálózatok (család, barátok, } \\
\text { egyetemi társak, szakmai hálózatok, közösségi média) } \\
\text { fenntartása, } \\
\text { kapcsolatok építése és ápolása új munkahelyi } \\
\text { környezetben (új kollégák, mentor, tanári közösség, } \\
\text { szülők, gyerekek) }\end{array}$ \\
\hline Wellbeing & Motivációs dimenzió: \\
\hline (fóllét) & $\begin{array}{l}\text { - személyes jóllét (mentális egészség, a stressz } \\
\text { felismerése és reagálás rá, egészséges életmód) } \\
\text { a munka és a magánélet egyensúlyának menedzselése } \\
\text { (a munkához nem köthető tevékenységek iránti } \\
\text { érdeklődés fenntartása, időmenedzsment), } \\
\text { - a szakmával kapcsolatos motiváció fenntartása (belső } \\
\text { motiváció, optimista gondolkodás, kitartás, } \\
\text { énhatékonyság) }\end{array}$ \\
\hline Taking initiative & Szakmai dimenzió: \\
\hline (Kezdeményezés) & $\begin{array}{l}\text { - problémamegoldás (rugalmas gondolkodás, a } \\
\text { problémamegoldás folyamata, segítségkérés) } \\
\text { - folyamatos szakmai tanulás (a szakmával való } \\
\text { foglalkozás lehetőségei, célok kitúzése) } \\
\text { - hatékony kommunikáció (értő figyelem, asszertív } \\
\text { kommunikáció, bekapcsolódás és a határok kijelölése) }\end{array}$ \\
\hline Emotions & Érzelmi dimenzió: \\
\hline (Érzelmek) & $\begin{array}{ll}\text { - } & \text { az érzelmi tudatosság fejlesztése (érzelmek felismerése, } \\
\text { - érzelmi reakciók, viselkedés) } & \text { érzelemszabályozás (érzelemszabályozási stratégiák, az } \\
\text { osztály légköre) } \\
\text { - }\end{array}$ \\
\hline
\end{tabular}

1. táblázat. A BRiTE moduljai és a modulok témakörei

A modulok önértékelési kérdőívek kitöltésével kezdődnek, amelyek a modul nagyobb tartalmi egységeire, az azzal kapcsolatos szokásokra, készségekre kérdeznek rá. A válaszok alapján a rendszer személyre szabja a tanulási tartalmat, azaz színkódokkal jelzi mindenki számára a javasolt sorrendet. Minden modul tartalmaz önreflexiót segítő kérdéseket, a rezilienciához fontos készségekkel, stratégiákkal kapcsolatos információkat, tippeket, videókat, helyzeteket, amelyeket a felhasználók megoldhatnak, és visszajelzést kapnak megoldásaikra, szakirodalmi összefoglalásokat és utalásokat az ausztráliai tanári szakmai standardokra. A tanulási tartalom felhasználóbarát, a modulok személyre szabhatóak, mindenki létrehozhatja a saját online tanulási felületét, eszköztárát videókkal, jegyzetekkel, 
tartalmakkal és személyes fejlődési/tanulási tervekkel. A modulok sikeres teljesítése után a résztvevők oklevelet kapnak.

A BRiTE a pedagógusképzések oktatói számára elérhetővé tesz egy rövid útmutatót, amely részletesen bemutatja a koncepciót, az egyes modulok tartalmát és azt, milyen képzési követelményeket, szakmai standardokat valósíthatnak meg, érhetnek el segítségükkel. Az egykori résztvevők ajánlásai, értékelései és a felhasználási tippek figyelemfelkeltővé és jól átláthatóvá teszik a kiadványt és az online képzési tartalmat bárki számára.

A BRiTE kidolgozásában részt vevő Mansfield és munkatársai (2016b) a szakirodalom részletes elemzése során összegyüjtötték a leggyakoribb ajánlásokat, amelyeket a pedagógusképzés számára fogalmaztak meg a kutatók. A megküzdési stratégiák, az idő- és stressz-menedzsment, az asszertivitás, az érzelmi kompetenciák, a társas készségek, az önszabályozás és a motiváció mind olyan fontos stratégiák, amelyeknek helyet kell szorítani a pedagógusképzésben. Mindezek mellett külön hangsúlyozzák, hogy az aktuális szocio-kulturális környezetből adódó speciális kihívások menedzselésének megtanítása is fontos lenne ebben az időszakban.

A BRiTE nyomán született meg a tanári rezilienciát erősítő európai projekt: Enhancing Teacher Resilience in Europe (ENTREE) (2013-2015), majd pedig a Staying BriTE, ${ }^{5}$ amely 2017-től az előző projekt eredményeit ágyazza be a mindennapi pedagógusképzés gyakorlatába, ezzel nyújtva segítséget a felsőoktatásban a pedagógusképzők széles köre számára. Mindeközben a kollaboratív munka során a projekt célja nemzeti és nemzetközi kapcsolatrendszerek kiépítése is.

Az ENTREE projekt eredményeként a BRiTE-hez hasonlóan jelenléti és online képzési tartalmak születtek. Itt hat modul foglalja össze a pedagógusok számára a rezilienciával és annak fejlesztésével kapcsolatos legfontosabb témákat, területeket. Ezek a következő: reziliencia, kapcsolatok építése, érzelmi jóllét, stresszel való megküzdés, hatékony tanítás és osztálymenedzsment. Az ötnyelvü online platformra ugyanúgy ingyenesen lehet regisztrálni és teljesíteni a modulokat, mint a BRiTE programnál. Habár az ENTREE ${ }^{6}$ sok mindenben épít a BRiTE projektre, az online platform megjelenésében, tartalmában, gyakorlatorientáltságában, interaktivitásában és közvetlenségében is elmarad az ausztráliai platformtól.

\footnotetext{
${ }^{5}$ Honlapja: https://www.stayingbrite.edu.au/

${ }^{6}$ http://www.entree-online.eu/ - Az oldal egy önálló tanulásra alkalmas interaktív online felület.
} 
Fernandes és munkatársai (2021) az ENTREE projekt adaptálásaként Portugáliában jelenléti képzésben megvalósult Pozitív nevelés programról számolnak be, amelyben a fentebb már említett hat ENTREE modult megelőzte egy pozitív pszichológiára alapozó, a képzés elméleti keretét biztosító modul. Az új, központi helyet elfoglaló modul (Nevelés a jóllétért) a pozitív pszichológia két meghatározó alakjának, Barbara Fredericksonnak a pozitív érzelmek elméletét és Martin Seligmannak a PERMA modelljét ${ }^{7}$ veszi alapul. A hét modul között dinamikus kapcsolatot alkottak a képzés kidolgozói: már az első központi modul felvetette a reziliencia fő témaköreit, vagyis a következő hat moduléit, az ENTREE projektből adaptált modulokba pedig mindenhol beépítettek egy-egy olyan részt, ami a pozitív nevelésre reflektált. A modulokat a résztvevők igényeihez, érdeklődéséhez szabták a képzők. Korthagen (2001 idézi Fernandes et al., 2021) realisztikus továbbképzési modelljéhez híven folyamatosan a résztvevők által hozott példákra, esetekre, tapasztalatokra építettek, és támogatták az önreflexiót és a reflexiót, ami a szakmai tanulás tapasztalati, társas, konstruktív jellegét erősítette. A résztvevőkkel készített félig strukturált interjúk alapján a képzés hasznosnak bizonyult: mind személyes, mind szakmai életükre, mind pedig társas kapcsolataikra hatással volt, fejlesztette konfliktuskezelési képességeiket, rezilienciájukat (Fernandes et al., 2021).

Egy hazai jó gyakorlat a Balázs és Szalay (2017) által bemutatott Hallgatói Sikeresség Támogatása (HASIT) program, amelynek keretében a Dunaújvárosi Egyetem oktatói egy ún. szalutogén pedagógián alapuló lelki ellenálló képességet erősítő képzésen vettek részt. A szalutogén pedagógia értelmezésükben egy olyan „önbecsülést támogató és a személyiségbeli növekedést elősegítő nevelési/oktatási gyakorlat” (Balázs \& Szalay, 2017, p. 73), amely kiemelten figyel a pedagógus lelki egészségére, koherenciaérzetére, ${ }^{8}$ ez ugyanis sokszor nagyobb hatással van a tanulókra, mint az oktatott tartalom. Éppen ezért a képzésben központi szerepet kapott az önismeret, a testtudat, a szakmai önreflexió és a stresszkezelés képességének fejlesztése. Mindezekhez test- és érzelemorientált önismereti gyakorlatokat,

\footnotetext{
${ }^{7}$ A PERMA modell elemei: P - Positive Emotion (pozitív érzelmek); E - Engagement (elköteleződés); R - Relationships (kapcsolatok); M - Meaning (értelem, jelentésteliség); A - Accomplishments (eredmények, teljesítmények).

${ }^{8}$ Balázs és Szalay (2017) szerint ahhoz, hogy az ember lelki immunrendszere jól működjön, elengedhetetlen az egyén bizakodó hozzáállása az élet kihívásaihoz, egyfajta koherencia-érzet megélése. Ez a koherencia-érzet pedig akkor valósul meg, ha az egyén érti, felismeri élete eseményei között az összefüggéseket, képes kezelni a kihívásokat, mert tudja, hogy birtokában vannak a megküzdéshez szükséges erőforrások, és nem utolsó sorban képes értelmet adni életének, és érdemesnek érzi magát arra, hogy megvalósítsa terveit.
} 
feladatorientált, érzelemközpontú megküzdési stratégiákat használtak, amelyek segítették a résztvevőket saját erőforrásaik felfedezésében, az egyéni, interperszonális, szervezeti és társadalmi-kulturális szintek kölcsönhatásának megértésében, saját önfejlesztő tevékenységük megtervezésében.

Habár a bemutatott programokat nem a DIMoR-modell alapján dolgozták ki, mindegyik program igyekszik az egyéni képességfejlesztés és erőforrás-feltárás mellett a társas kapcsolatokra, a közösségre, a szủkebb-tágabb társadalmi, gazdasági, kulturális kontextusra reagálni. A programok mind kiemelik a reziliencia fejlesztése során érintett különböző rendszerek (például az egyén mint bio-pszichoszociális rendszer, az iskola mint rendszer, az oktatási rendszer, a társadalmi rendszer) egymásba ágyazottságát és egymásra hatását, ami a DIMoR-modellnek is egyik alaptétele. A programok nem a kockázati tényezők, nehézségek elkerülésére tanítanak, hanem azoknak a belső és külső protektív faktoroknak a tudatosítására, fejlesztésére, amelyek segítenek a nehéz helyzetekben. A reflektivitás fejlesztése mint minden képzési program visszatérő eleme épp ezért kiemelt jelentőségü.

A DIMor-modell kidolgozói (Middleton \& Millicam, 2020; Templeton et al., 2020) külön felhívták a figyelmet arra, milyen veszélyeket rejt, ha a kontextust kihagyják a számításból. Bármelyik képzés adaptálásánál figyelembe kell venni, ki fogja gyakorlatba ültetni a programot, mert ugyanaz a módszer másképp múködik egyik vagy másik képző, pedagógus kezében. Shafi és munkatársai (2020), éppúgy mint Mansfield (2021), rávilágítanak arra, hogy egy sor rendszerbeli faktor (oktatáspolitika, oktatásszabályozás, stb.) befolyásolja azt, ahogyan maguk a pedagógusok és a képzők konceptualizálják a reziliencia fejlesztését. A pedagógus, tréner azonban csak egy személy, aki saját szakmai, kulturális, társadalmi rendszerébe ágyazottan értelmezi a világot, saját feladatát, az illető képzési programot (Templeton, Shafi \& Pritchard, 2020). A programok implementálása akkor lehet sikeres, ha ez a személy is felismeri beágyazottságát ezekbe a rendszerekbe, kulturális sémákba, és tisztába kerül saját alapvető motivációival.

Ugyanakkor figyelembe kell vennünk azt is, hogy a reziliencia fejlesztése nem képes megoldani minden problémát. Trethewey és Reynolds (2019) az egészségügyi rendszerben dolgozók kiégése és túlterheltsége okán fejti ki véleményét, miszerint semmilyen rezilienciafejlesztő tréning nem képes azokat a szervezeti, rendszerszintű problémákat megoldani, amit egy rendszer alulfinanszírozása, túlfeszítettsége okoz. Szerintük sokkal hatékonyabb, ha megfelelő mennyiségű időt biztosítanak a dolgozóknak kikapcsolódásra, képzésre, szakmai fejlődésre, mint ha 
Pedagógusképzés • 19(47), 2020/3-4.

készségeket fejlesztenek. Ez a figyelmeztetés a pedagógusképzésben és -továbbképzésben is érvényes: a megfelelő szervezeti feltételek, társadalmi és anyagi megbecsültség hiányában a pedagógusok és a pedagógusjelöltek rezilienciájának fejlesztése csak „gyorssegély”, „tüneti kezelés”, ami a valódi problémákat nem orvosolja.

\section{Irodalom}

Balázs, L. \& Szalay, Gy. (2017). A tanári reziliencia fejlesztésének lehetőségei: Egy hazai jó gyakorlat bemutatása. In Szőke-Milinte, E. (Ed.), A kommunikációs kompetencia fejlesztése a különbözö korcsoportokban (pp. 71-80). Hungarovox Kiadó.

Beltman, S., Mansfield, C. F. \& Price, A. (2011). Thriving not just surviving: A review of research on teacher resilience. Educational Research Review, 6(3), 185207. https://doi.org/10.1016/j.edurev.2011.09.001

Beltman, S. (2021). Understanding and Examining Teacher Resilience from Multiple Perspectives In Mansfield, C. F. (Ed.), Cultivating Teacher Resilience, International Approaches, Applications and Impact (pp. 11-26.). Springer Nature Singapore Pte Ltd. https://doi.org/10.1007/978-981-15-5963-1_2

Bordás, A. (2012a). Pedagógusok szakmai tanuló közösségei szociokulturális konstruktivista megvilágításban. In Pusztai, G., Fenyő, I. \& Engler, Á. (Eds.), A tanárok tanárának lenni. Tanulmányok Szabó László Tamás 70. születésnapjára (pp. 226-246). CHERD-Hungary.

Bordás, A. (2012b). Valós igények teljesülése a “mintha” birodalmában. A Nagyváradi Drámapedagógiai Műhely mint szakmai tanuló közösség. In Fóris-Ferenczi, R. \& Demény, P. (Eds.), Interaktív eszközök és módszerek a tanulási folyamatban (pp. 159-170). Egyetemi Műhely Kiadó.

Bordás, A. (2017). Romániai magyar pedagógusok szakmai fejlódése - narratívák a rendszeren belülről. $\mathrm{PhD}$ disszertáció. Kézirat.

Botou, A., Iro Mylonakou-Keke, O. K. \& Tsergas, N. (2017). Primary School Teachers' Resilience during the Economic Crisis in Greece. Psychology, 2017(8), 131159, http://dx.doi.org/10.4236/psych.2017.81009.

Ceglédi, T. (2012). Reziliens életutak, avagy A hátrányok ellenére sikeresen kibontakozó iskolai karrier. Szociológiai Szemle, 22(2), 85-110. https:// szociologia.hu/dynamic/szocszemle_2012_2_cegledi.PDF (2020. 04. 09.)

Ceglédi, T. (2018). Ugródeszkán. Reziliencia és társadalmi egyenlőtlenségek a felsóoktatásban. CHERD-Hungary.

Cicchetti, D. \& Lynch, M. (1993). Toward an ecological/transactional model of community violence and child maltreatment: Consequences for children's de- 
velopment. Psychiatry: Interpersonal and Biological Processes, 56, 96-118. DOI:10.1521/00 332747.1993 .11024624

Crane, M. F., Searle, B. J., Kangas, M. \& Nwiran, Y. (2018). How resilience is strengthened by exposure to stressors: the systematic self-reflection model of resilience strengthening. Anxiety, Stress, \& Coping. http://doi.org/ 10.1080/10615806.2018.1506640.

Donders, P. C. (2020). Reziliencia. Hogyan fejlesszük lelki ellenálló képességünket, és elözzük meg a kiégést? Harmat Kiadó.

Erdei, R. (2014-2015). Reziliencia a pedagógiában - a kockázat ellensúlyozása pedagógiai eszközökkel. Pedagógusképzés, 12-13(41-42), 27-43. http://doi.org/ 10.37205/TEL-hun.2014-2015.02.

F. Lassú, Z., Serfőző, M., Sándor, M., Kolosai, N. \& Pálffy, Z. (2015). Családi struktúra, szülői bánásmód és lélektani rugalmasság összefüggései serdülőkorban. Alkalmazott pszichológia, 15(1), 77-92. DOI: 10.17627/ALKPSZICH.2015.1.77

Fehérvári, A., Varga, A. \& Ceglédi, T. (2018). Hátrányos helyzetű diákok iskolai útja. Reziliencia és inklúzió. In Fehérvári, A. \& Varga, A. (Eds.), Reziliencia és inklúzió az Arany fános Programokban (pp. 17-46). Pécsi Tudományegyetem Bölcsészettudományi Kar Neveléstudományi Intézet Romológia és Nevelésszociológia Tanszék, Wlislocki Henrik Szakkollégium.

Fernandes, L., Gouveia, M. J., Silva, J. C. \& Peixoto, F. (2021). 'Positive Education': A Professional Learning Programme to Foster Teachers' Resilience and WellBeing. In Mansfield, C. F. (Ed.), Cultivating Teacher Resilience, International Approaches, Applications and Impact (pp. 103-124). Springer Nature Singapore Pte Ltd. https://doi.org/10.1007/978-981-15-5963-1_7

Gibbs, S. \& Miller, A. (2014). Teachers' resilience and well-being: a role for educational psychology. Teachers and Teaching: theory and practice 20(5), 609-621. DOI: $10.1080 / 13540602.2013 .844408$

Gu, Q. \& Day, C. (2007). Teacher resilience: A necessary condition for effectiveness. Teaching and Teacher Education, 23, 1302-1316. DOI:10.1016/ j.tate.2006.06.006

Gu, Q. \& Day, C. (2013). Challenges to teacher resilience: conditions count. British Educational Research fournal, 39(1), 22-44. http://dx.doi.org/ 10.1080/01411 926.2011.623152

Hart, A. \& B. Heaver. (2015). Resilience Approaches to Supporting Young People's Mental Health: Appraising the Evidence Base for Schools and Communities. University of Brighton/Boingboing.

Herrman, H., Stewart, D., Diaz-Granados, N., Berger, E., Jackson, B. \& Yuen, T. (2011). What is Resilience? The Canadian fournal of Psychiatry, 56(5), 258-265. https://doi.org/10.1177/0 70674371105600504 
Hiver, P. (2018). Teachstrong: The power of resilience for L2 practitioners. In Mercer, S. \& Kostoulas, A. (Eds.), Language Teacher Psychology (pp. 231-246). Multilingual Matters. DOI:10.21832/9781783099467-018

Homoki, A. (2014). Az iskola és a gyermekvédelmi intézmények rezilienciát elősegítő hatásai. In Ceglédi, T., Gál, A. \& Nagy, Z. (Eds.), Határtalan oktatáskutatás. Tanulmányok a 75 éves Kozma Tamás tiszteletére. Régió és Oktatás IX. (pp. 4557). Debreceni Egyetem Felsőoktatási Kutató és Fejlesztő Központja (CHERDHungary).

Homoki, A. (2016). A reziliencia recepciója a hazai neveléstudományi kutatásokban. In Pusztai, G., Bocsi, V. \& Ceglédi, T. (Eds.), A felsőoktatás (hozzáadott) értéke. Közelítések az intézményi hozzájárulás empirikus megragadásához. (pp.7889). Partium Könyvkiadó - Personal Problems Solution - Új Mandátum Könyvkiadó.

Homoki, A. (2020). A reziliencia egyéni nézőpontú megközelítései a human segítés nemzetközi és hazai gyakorlatában. Kucsera, Cs. \& Rácz, A. (Eds.), Szociálpedagógia 15/2020. Életfordulók - gyermekkortól időskorig (pp. 52-68). Apor Vilmos Katolikus Főiskola.

Homoki, A. \& Czinderi, K. (2015). A gyermekvédelmi szempontú rezilienciakutatás eredményei Magyarország két régiójának LHH térségében. Esély, 2015/6, 61-81. http://www.esely.org/kiadvanyok/2015_6/2015-6_2-2_Homoki-Czinderi_Gyermekvedelmi_szempontu.pdf (2021. 04. 07.)

Hüse, L. \& Ceglédi, T. (2018). „Érett dió is lehetek” - A megterhelo életesemények és a reziliencia hatása az iskolai pályafutásra. Evangélikus Roma Szakkollégium.

Johnson, B., Down, B., Le Cornu, R., Peters, J., Sullivan, A., Pearce, J., et al. (2010). Conditions that support early career teacher resilience. Refereed paper presented at 'Teacher education for a sustainable future', the annual conference of the annual conference of the Australian Teacher Education Association (ATEA). Townsville, 4-7 July. DOI: 10.1080/13540 602.2014.937957

Kóródi, K. \& Szabó, É. (2019). A tanulmányi reziliencia értelmezése: kutatási, prevenciós és intervenciós lehetőségek. Magyar Pszichológiai Szemle, 74(4/6), 527545. https://doi.org/10.1556/0016.2019.74.4.6

Kovács, E. \& Fekete, A. (2014). The Professional Identity and Achievement of Education Majors in the Cross-Border Region of Hungary, Romania and Ukraine. Education's Role in Preparing Globally Competent Citizens (pp. 136-144). Bulgarian Comparative Education Society. https://eric.ed.gov/?id=ED598 073 (2021.03.03.)

Kozma, K. \& Ceglédi, T. (2020). „Akinek van bátorsága a gesztenyét lebontani”. Reziliens életúttal a pedagógus pályán. Acta Medicinae et Sociologica, 11(31), 85-101. https://doi.org/10.19055/ams.2020.11/31/8 
Lazsádi, C. (2015). Óvodás gyerekek megküzdési stratégiájának és a családjaik szocio-demográfiai változóinak összefüggésvizsgálata. Erdélyi Társadalom, 13(1), 131-147. http://doi.org/10.17177/77 171.9.

Le Cornu, R. (2013). Building Early Career Teacher Resilience: The Role of Relationships. Australian fournal of Teacher Education, 38(4).

DOI: $10.14221 /$ ajte.2013v38n4.4

Luthar, S. S. \& Cicchetti, D. (2000). The construct of resilience: Implications for interventions and social policies. Development and Psychopathology, 12(4), 857885. https://www.ncbi.nlm.nih.gov/pmc/articles/PMC1 903 337/ (2021. 04. 07.)

Mansfield, C. F. (Ed.) (2021). Cultivating Teacher Resilience International Approaches, Applications and Impact. Springer

Mansfield, C. F. \& Beltman, S. (2015). Annotated Bibliography of Teacher Resilience - BRiTE. Brite.edu.au.

https://www.brite.edu.au/annotated-bibliography-of-teacher-resilience (2021. 08. 20)

Mansfield, C. F., Beltman, S., Broadley, T. \& Weatherby-Fell, N. (2016b). Building resilience in teacher education: An evidenced informed framework. Teaching and Teacher Education, 54, 77-87. DOI: 10.1016/j.tate.2015.11.016

Mansfield, C. F., Beltman, S., Price, A. \& McConney, A. (2012). "Don't sweat the small stuff": Understanding teacher resilience at the chalkface. Teaching and Teacher Education, 28(3), 357-367.

http://researchrepository.murdoch.edu.au/6291 (2021. 06. 22)

Mansfield, C. F., Beltman, S., Weatherby-Fell, N. \& Broadley, T. (2016a). Classroom ready? Building resilience in teacher education. In R. Brandenberg, S. McDonough, J. Burke \& S. White (Eds.), Teacher Education: Innovation, intervention and impact (pp. 211-229). Springer.

Masten, A., Best, K. M. \& Garmezy, N. (1990). Resilience and development: Contributions from the study of children who overcome adversity. Development and Psychopathology, 2(4), 425-444. DOI: 10.1017/S0 954579400005812

Máté, D. (2015). Reziliens romák identitáskonstrukciói. Erdélyi Társadalom, 13(1), 43-55. DOI: $10.17177 / 77171.3$

Middleton, T. (2020). Resilience in Practitioners Working in the Field of SEND. Springer.

Middleton, T. \& Millican, R. (2020). 'Teaching' Resilience: Systems, Peadagogies and Programmes. In Shafi, A., Middleton, T., Millican, R. \& Templeton, S. (Eds.), Reconsidering Resilience in Education. An Exploration using the Dynamic Interactive Model of Resilience (pp. 79-92). Springer Nature Switzerland AG. 
Patakfalvi-Czirják, Á., Papp, Z. A. \& Neumann, E. (2018). Az iskola nem sziget. Oktatási és társadalmi reziliencia multietnikus környezetben. Educatio, 27(3), 474-480. DOI:10.1556/2063.27.2018.3.9

Shafi, A. a. (2020). Resilience in Education: Hindrance and Opportunity. In Shafi, A., Middleton, T., Millican, R. \& Templeton, S. (Eds.), Reconsidering Resilience in Education. An Exploration using the Dynamic Interactive Model of Resilience (pp. 59-78). Springer Nature Switzerland AG.

Shafi, A. a. \& Templeton, S. (2020). Towards a Dynamic Interactive Model of Resilience. In Shafi, A., Middleton, T., Millican, R. \& Templeton, S. (Eds.), Reconsidering Resilience in Education. An Exploration using the Dynamic Interactive Model of Resilience (pp. 17-39). Springer Nature Switzerland AG.

Shafi, A. a., Middleton, T., Millican, R. \& Templeton, S. (2020). Reconsidering Resilience in Education. An Exploration using the Dynamic Interactive Model of Resilience. Springer Nature Switzerland AG., DOI: 10.1007/978-3-030-49 236-6.

Sikma, L. (2021). Building Resilience: Using BRiTE with Beginning Teachers in the United States. In Mansfield, C. F. (Ed.), Cultivating Teacher Resilience. International Approaches, Applications and Impact (pp. 85-101). Springer Nature Singapore Pte Ltd. DOI: 10.1007/978-981-15-5963-1_6

Stoll, L. \& Louis, K. S. (2007). Professional Learning Communities. Divergence, Depth and Dilemmas. Open University Press.

Stoll, L., Bolam, R., McMahon, A., Wallace, M. \& Thomas, S. (2006). Professional learning communities: A review of the literature. Fournal of Educational Change, 7(4), 221-258. DOI: 10.1007/s10 833-006-0001-8

Sz. Makó, H. \& Kiss, E. C. (2015). A művi abortusz nők mentális egészségre gyakorolt rövid és hosszú távú tatása a reziliencia, coping és neuroticizmus jellemzőkkel összefüggésben. Alkalmazot Pszichológia, 15(1), 93-109. DOI: 10.17627/ALKPSZICH.2015.1.93

Szokolszky, A. \& V. Komlósi, A. (2015). A „reziliencia-gondolkodás” felemelkedése - ökológiai és pszichológiai megközelítések. Alkalmazott pszichológia, 15(1), 11-26. DOI: 10.17627/ALKPSZICH.2015.1.11

Szokolszky, Á., Palatinus, K. \& Palatinus, Z. (2015). A reziliencia mint komplex dinamikus fejlődési rendszerek sajátossága. Alkalmazott Pszichológia, 15(1), 4360. DOI: 10.17627/ALKPSZICH.2015.1.43

Tait, M. (2008). Resilience as a Contributor to Novice Teacher Success, Commitment, and Retention. Teacher Education Quarterly, Fall 2008, 57-75. https:// files.eric.ed.gov/fulltext/EJ838 701.pdf (2021. 04. 12.)

Templeton, S., Shafi, A. a. \& Pritchard, R. (2020). Educator Conceptualisations of Emotional Education and the Development of Resilience. In Shafi, A. a., Middleton, T., Millican, R. \& Templeton, S., (Eds.), Reconsidering Resilience in Edu- 
cation. An Exploration using the Dynamic Interactive Model of Resilience (pp. 151-166). Springer Nature Switzerland AG, https://doi.org/10.1007/978-3-03049236-6_10.

Tompa, B. (2013). Pedagóguspályák. Utak és lehetőségek a kiégés és szakmai kitejesedés között. Alkalmazott Pszichológia, 13(3), 7-25.

Tóth, E., Fejes, J. B., Patai, J. \& Csapó, B. (2016). Reziliencia a magyar oktatási rendszerben egy longitudinális program adatainak tükrében. Magyar Pedagógia, 116(3), 339-363. DOI: 10.17670/MPed.2016.3.339

Trethewey, S. P. \& Reynolds, E. K. M. (2020). Burnout: is resilience training the solution? The Clinical Teacher, 2020/17, 109-110. DOI: 10.1111/tct.13105

Vicente de Vera García, M. I. (2020). Resilient Keys to Burnout Prevention in High School Teachers. Open Access fournal of Biomedical Science, November 3(2), 691-699. http://dx.doi.org/10.38125/OAJBS.000232.

Wald, J., Taylor, S., Asmundson, G. J., Jang, K. L. \& Stapleton, J. (2006). Literature Review of Concepts: Psychological Resiliency. Final Report. Defence R\&D Canada. W7711-057 959/A

Wang, Y. (2021). Building Teachers' Resilience: Practical Applications for Teacher Education of China. Frontiers in Psychology. 12:738 606. DOI: 10.3389/ fpsyg.2021.738606

Waters, P. (2019). Relationships, Resources, Resilience: Professional Learning Communities to Improve Teacher Retention. Paper presented at the annual meeting of the American Educational Research Association, Toronto, Canada, April 2019. https://files.eric.ed.gov/fulltext/ED598 821.pdf (2021. 06. 20.)

Weatherby-Fell, N., Neilsen-Hewett, C. \& Duchesne, S. (2021). Building Resilience for Early Years Teachers. In Mansfield, C. F. (Ed.), Cultivating Teacher Resilience, International Approaches, Applications and Impact (pp. 51-68). Springer Nature Singapore Pte Ltd. https://doi.org/10.1007/978-981-15-5963-1_4 


\section{Investigation of resilience among teachers and in teacher education}

This study revolves around the concept of resilience and its application in the educational sphere. In the Hungarian-language educational literature we mainly encounter the concept and examination of academic resilience. The aim of this study is to present a holistic approach based on system theory, which is more suitable to the world of teacher research and is able to capture the concept of professional resilience in its complexity. This dynamic and interactive model of resilience provides an opportunity to rethink both the institutional educational environment and pre-service and in-service teacher training so that they can foster the development of resilience.

Keywords: resilience, teacher retention, resilient teacher, retention, dynamic interactive model of resilience 